\title{
FTIR Analysis of Liquefaction Product of Long Flame Coal by White-rot Fungi
}

\author{
Kai-yi SHI ${ }^{1,2, a,{ }^{*}}$, Jian LONG ${ }^{1, b}$, De-guang KONG ${ }^{1, c}$ Lei-Xu XIAO $^{3, d}$ \\ ${ }^{1}$ Department of Chemistry and Chemical Engineering, Liupanshui normal college, Liupanshui, 553004, \\ China \\ ${ }^{2}$ Key Laboratory of Coal Processing and Efficient Utilization of Ministry of Education, China University \\ of Mining \& Technology, Xuzhou, 221008, China \\ ${ }^{3}$ Guizhou Qiangui Tianneng CNG Co. Ltd, Liupanshui, 553531, China

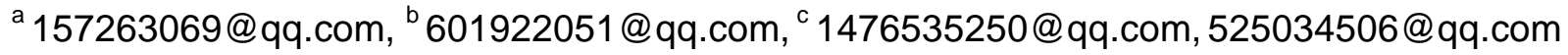 \\ ${ }^{*}$ Corresponding author: SHI Kai-yi
}

Keywords: long flame coal, liquefaction product, FTIR spectra, white-rot fungi.

Abstract. Liquefaction of low rank coal such as long flame coal by microorganisms is one of the most potential ways in coal clean utilization. To promote industrialized application, this paper focuses on structure of liquefaction product by infrared spectrometer. After that, software Peakfit v4.12 was used to peak separation fit the FTIR spectrum of liquefaction product and two structural parameters was calculated subsequently. Results show that liquefaction product is rich in acid amides N-H $(3173,3345$, $3436 \mathrm{~cm}^{-1}$ ) and $\mathrm{C}=\mathrm{O}$ in aldehyde/ester. Aromatic hydrogen ratio of liquefaction product is 0.686 , and the side chain length is 0.791 . In comparison Fushun long flame coal before microorganisms liquefaction, a conclusion can be obtained that coal macromolecule was broken up by enzymes excreted by white-rot fungi.

\section{Introduction}

Coal bio-liquefaction is a degradation process of coal macromolecule to low molecules or solution process of small molecules in coal by microorganisms excretion products such as enzymes ${ }^{[1]}$. Because of benefits such as mild reaction, no secondary pollution, etc, it is one of the most important part of coal clean efficient utilization, which has received extensive attention in worldwide since the first reported in early $1980 \mathrm{~s}^{[2-3]}$. However, over the past 30 years, coal bio-liquefaction is still at the stage of laboratory research, and fails to get the application in industry. One of the most important facts is the complex composition in liquefaction products, thus it is unable to gain high purity products.

Various modern analysis and testing technologies were used to analyzed bio-liquefaction product, while Fourier transform infrared spectroscopy is one of the most efficient ways in organic substance analysis ${ }^{[4]}$. Basaran ${ }^{[5]}$ analyzed raw coal and liquefaction product by FTIR and reported that raw coal is rich in groups of $\mathrm{CH}, \mathrm{C}=\mathrm{C}, \mathrm{CH}_{2}, \mathrm{CH}_{3}, \mathrm{C}-\mathrm{OH}$ and $\mathrm{COOH}$, and the FTIR spectrum of liquefaction product is similar with that of raw coal, except for absorbance of carbonyl group in $1701 \mathrm{~cm}^{-1}$ and that of symmetric methyl in tert-butyl in $1391 \mathrm{~cm}^{-1}$. Wang ${ }^{[6]}$ took lignite as research object, results show that FTIR spectra of raw coal and liquefaction product are similar except for $\mathrm{OH}$ absorption enhancement in $3424 \mathrm{~cm}^{-1}$, and additional aromatic ketone or conjugated carbonyl in $1385 \mathrm{~cm}^{-1}, 1096 \mathrm{~cm}^{-1}$. However, there is little report about long flame coal so far. This paper uses white-rot fungi selected by own laboratory to liquefy Fushun long flame coal, FTIR spectra of liquefaction was peakfited subsequently, and structural parameters were calculated at the end, which lays the foundation for bio-liquefaction mechanism. 


\section{Materials and methods}

\section{Coal sample}

Coal used in this paper was from Fushun (northeast China) western open mine. According to elemental analysis, it belongs to long flame coal. After crushing under $0.25 \mathrm{~mm}$, range between $0.25 \mathrm{~mm}$ and $0.15 \mathrm{~mm}$ was chosen as coal sample. In order to enhancing coal bio-liquefaction ratio, nitric acid was used to pretreated coal before microorganism liquefaction.

\section{Microorganism liquefaction}

Microorganism used in liquefaction was selected by own laboratory, according to identification report, it belongs to Deuteromycotina Moniliales Hypocrea and named Hypocrea lixii AH. Culture media in liquefaction is SMA media, with component as $40 \mathrm{~g}$ maltose, $10 \mathrm{~g}$ peptone, $20 \mathrm{~g}$ agar and $1000 \mathrm{~mL}$ water. White-rot fungi Hypocrea lixii AH was inoculated onto SMA media in $9 \mathrm{~cm}$ petri dish, after mycelium covering the media, Fushun nitric acid oxidized long flame coal was sprinkled evenly over the surface of mycelium, and then cultivated at $28^{\circ} \mathrm{C}$ incubator. After black drop formation on coal, it was extracted by pipette in clean bench for next step analysis.

\section{FTIR spectra analysis of liquefaction product}

Liquefaction black drop was analyzed by the Nicolet 380 IR absorption spectrum analyzer (Nicolet Company, USA). After drying, $\mathrm{KBr}$ was ground into powder and then pressed into sheets in tableting machine, liquefaction drop was added into pressed sheet. On the other way, liquefaction drop was dried in room temperature, and then fully mixed with $\mathrm{KBr}$, and been pressed into sheets in tableting machine. Finally the pressed sheets were scanned for 32 times with the scan range of $4000-450 \mathrm{~cm}^{-1}$ and a resolution of $4 \mathrm{~cm}^{-1}$.

\section{Peak Fitting of Spectrum}

As the coal liquefaction product's composition is very complex, superposition is easy to caused in spectrum, this is very unfavorable for spectral interpretation. Therefore, in this study, software Peakfit v4.12 was used in the peak separation processing of the spectrum of superposition. According to the second derivative diagram of the spectrum to determine the approximate location and number of the initial solution stack fitting peak, and by adjusting the peak height, peak width, peak shape to optimize the fitting peak. The more of the correlation coefficient $R^{2}$ between the fitting line and the original line, the smaller of the variance, represented the better of the fitting effect.

\section{Results and discussion}

\section{FTIR spectra of liquefaction product}

FTIR spectra of liquefaction drop and dried liquefaction product were shown as Figure 1. In view of influence of water in liquefaction drop, a big absorbance peak representing $\mathrm{OH}$ (ranging from $3600 \mathrm{~cm}^{-1}$ to $3000 \mathrm{~cm}^{-1}$ ) appears in liquefaction drop FTIR spectrum. Besides, two big peak in 1750-1500 $\mathrm{cm}^{-1}$ (absorbance of $\mathrm{C}=\mathrm{C}$ in aromatic ring, and $\mathrm{C}=\mathrm{O}$ in carboxylic acid and/or ether) and around $700 \mathrm{~cm}^{-1}$ (absorbance of aromatic hydrocarbon). The existence of water overlaps characteristic absorption peaks of liquefaction product, while been dried, these functional groups show up, as shown in Figure 1.

Software peakfit was used to peak FTIR spectrum of dried liquefaction product. After adjusting and revising height and width each small peak, 40 small peaks were obtained, with square of correlation coefficient is 0.987 , and the functional groups belonging as show in Table 1. Liquefaction product is rich in $\mathrm{N}-\mathrm{H}$ in amide $\left(3173 \mathrm{~cm}^{-1}, 3345 \mathrm{~cm}^{-1}\right.$ and $\left.3436 \mathrm{~cm}^{-1}\right)$, which accounts for $56.75 \%$ of total peak area, secondly is intermolecular hydrogen bond $\left(3496 \mathrm{~cm}^{-1}, 3560 \mathrm{~cm}^{-1}, 3582 \mathrm{~cm}^{-1}\right.$ and $\left.3600 \mathrm{~cm}^{-1}\right)$, which accounts for that of $8.75 \%$, and then is carboxylate ion $\left(1398 \mathrm{~cm}^{-1}\right)$, accounting that of $6.76 \%$. Besides 
that, unsaturated bond $\mathrm{C}=\mathrm{O}$ in aldehydes, ketones, esters, amides, and $\mathrm{C}=\mathrm{C}$ in aromatic hydrocarbon are also been detected also. According to Table 1, functional groups of Ar-N (1320 cm $\left.\mathrm{cm}^{-1}\right), \mathrm{NO}_{2}\left(1558 \mathrm{~cm}^{-1}\right)$, enol ether and/or aromatic ether $\left(1044 \mathrm{~cm}^{-1}\right)$ exist in liquefaction product. However, no absorbance of aliphatic methoxy $\left(2830-2815 \mathrm{~cm}^{-1}\right)$ and aromatic methoxy $\left(2850 \mathrm{~cm}^{-1}\right)$ are no been detected.

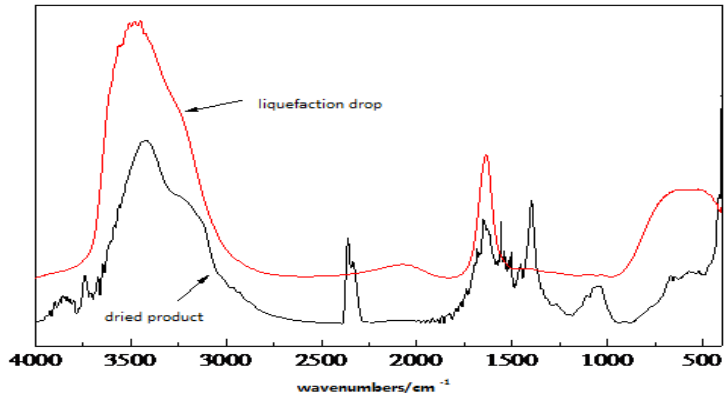

Figure 1 FTIR spectra of black drops and dried liquefaction product

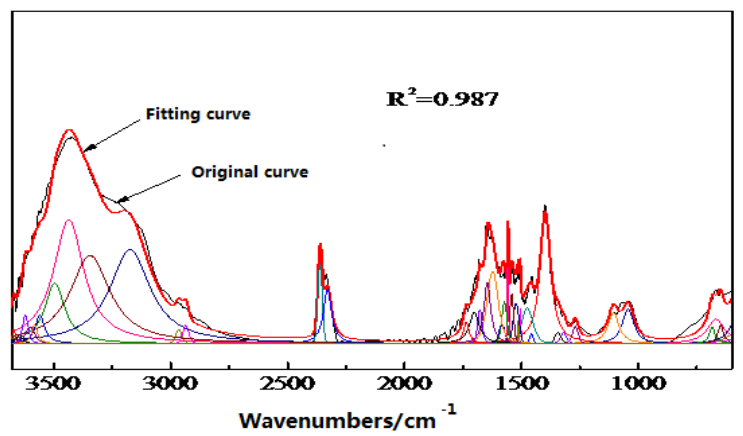

Figure 2 FTIR spectra peakfit of dried liquefaction product

Table 1 Belonging of FTIR spectrum peakfit of dried solubilized coal

\begin{tabular}{|c|c|c|c|c|}
\hline area $/ \mathrm{cm}^{-1}$ & area & $\begin{array}{l}\text { Relative } \\
\text { area/\% }\end{array}$ & Belonging & $\begin{array}{l}\text { Peak } \\
\text { shape }\end{array}$ \\
\hline 648 & 0.83 & 0.53 & $\mathrm{~N}-\mathrm{H}$ & $\mathrm{L}$ \\
\hline 668 & 3.35 & 2.15 & Single substituted aromatic & $\mathrm{L}$ \\
\hline 684 & 0.74 & 0.48 & Meta substituted aromatic & $\mathrm{L}$ \\
\hline 714 & 0.89 & 0.57 & Meta substituted aromatic & M \\
\hline 744 & 0.53 & 0.34 & Ortho substituted aromatic & M \\
\hline 767 & 0.46 & 0.30 & Ortho substituted aromatic & M \\
\hline 1044 & 3.00 & 1.93 & $=\mathrm{C}-\mathrm{O}-\mathrm{C}$ & M \\
\hline 1107 & 2.64 & 1.70 & $\mathrm{C}=\mathrm{C}$ connected with $\mathrm{C}-\mathrm{C}=\mathrm{O}$ & $\mathrm{L}$ \\
\hline 1269 & 0.62 & 0.40 & $\mathrm{C}-\mathrm{N}$ in amide & M \\
\hline 1320 & 0.41 & 0.26 & Ar-N in Ar-N-H (R) & M \\
\hline 1345 & 0.41 & 0.26 & $\mathrm{NO}_{2}$ in aromatic & M \\
\hline 1398 & 10.51 & 6.76 & $-\mathrm{COO}^{-}$ & $\mathrm{L}$ \\
\hline 1458 & 0.22 & 0.14 & $\mathrm{CH}_{2}$ in ring aromatic & M \\
\hline 1475 & 2.50 & 1.61 & $\mathrm{CH}_{3}$ in side chain & M \\
\hline 1505 & 0.34 & 0.22 & $\mathrm{C}=\mathrm{C}$ in aromatic & $\mathrm{L}$ \\
\hline 1514 & 0.20 & 0.13 & $\mathrm{C}=\mathrm{C}$ in aromatic & $\mathrm{L}$ \\
\hline 1523 & 1.23 & 0.79 & $\mathrm{C}=\mathrm{C}$ in aromatic & G \\
\hline 1541 & 1.15 & 0.74 & $\mathrm{C}=\mathrm{C}$ in aromatic & M \\
\hline 1573 & 1.33 & 0.86 & $\mathrm{C}=\mathrm{C}$ in aromatic & M \\
\hline 1583 & 0.73 & 0.47 & $\mathrm{C}=\mathrm{C}$ in aromatic or $-\mathrm{COO}^{-}$ & M \\
\hline 1623 & 5.12 & 3.29 & $\mathrm{~N}-\mathrm{H}$ & M \\
\hline 1646 & 3.21 & 2.06 & $\begin{array}{c}\mathrm{C}=\mathrm{O} \text { in amide or substituted } \\
\text { benzoquinone }\end{array}$ & $\mathrm{L}$ \\
\hline 1678 & 0.99 & 0.64 & $\mathrm{C}=\mathrm{O}$ in substituted benzoquinone & M \\
\hline 1701 & 2.47 & 1.59 & $\mathrm{C}=\mathrm{O}$ in ketone & $\mathrm{L}$ \\
\hline 1736 & 0.96 & 0.62 & $\mathrm{C}=\mathrm{O}$ in ether & $\mathrm{L}$ \\
\hline 2330 & 3.48 & 2.24 & $\mathrm{CO}_{2}$ & $\mathrm{~L}$ \\
\hline 2361 & 1.87 & 1.20 & $\mathrm{CO}_{2}$ & $\mathrm{G}$ \\
\hline 2936 & 0.67 & 0.43 & $\mathrm{CH}_{2}$ & M \\
\hline
\end{tabular}




\begin{tabular}{ccccc}
\hline 2965 & 0.53 & 0.34 & $\mathrm{CH}_{3}$ & $\mathrm{M}$ \\
3173 & 30.23 & 19.43 & $\mathrm{~N}-\mathrm{H}$ in secondary amide & $\mathrm{L}$ \\
3345 & 28.00 & 18.00 & O-H or N-H in secondary amide & $\mathrm{L}$ \\
3436 & 30.04 & 19.31 & O-H or N-H in secondary amide & $\mathrm{L}$ \\
3496 & 9.68 & 6.22 & intermolecular hydrogen bond & $\mathrm{L}$ \\
3560 & 2.11 & 1.36 & intermolecular hydrogen bond & $\mathrm{L}$ \\
3582 & 0.83 & 0.53 & intermolecular hydrogen bond & $\mathrm{L}$ \\
3600 & 1.00 & 0.64 & intermolecular hydrogen bond & $\mathrm{M}$ \\
3621 & 1.04 & 0.67 & intermolecular hydrogen bond & $\mathrm{M}$ \\
3646 & 0.38 & 0.24 & intermolecular hydrogen bond & $\mathrm{L}$ \\
3671 & 0.26 & 0.17 & $\mathrm{H}_{2} \mathrm{O}$ & $\mathrm{M}$ \\
\hline
\end{tabular}

Note: L-Lorentz peak, G-Gaussian peak, M-Mixed peak

\section{Calculation of structural parameters of liquefaction}

According to FTIR analysis data, structural parameters such as aromatic hydrogen ratio, and side chain length can be calculated as follows:

(1) Aromatic hydrogen ratio $\left(f_{\mathrm{ar}}^{\mathrm{H}}\right)$ refers to ratio of aromatic hydrogen to total hydrogen, which assuming hydrogen molecular in liquefaction product exist only in two forms, aromatic hydrogen and fat hydrogen. The absorbance of fat hydrogen is the absorbance area of 2970-2800 $\mathrm{cm}^{-1}$, while that of aromatic hydrogen is the absorbance area of 900-690 $\mathrm{cm}^{-1}$, as shown in formula 1. Thus, aromatic hydrogen ratio of Fushun long flame coal liquefaction product is 0.686.

$$
f_{\mathrm{ar}}^{\mathrm{H}}=\frac{\mathrm{H}_{\mathrm{ar}}}{\mathrm{H}}=\frac{I\left(900-690 \mathrm{~cm}^{-1}\right)}{I\left(2970-2800 \mathrm{~cm}^{-1}\right)+I\left(900-690 \mathrm{~cm}^{-1}\right)}
$$

(2) Side chain length is one of the most important parameters in low rank coal, which can be calculated by comparing of $\mathrm{CH}_{3}$ and $\mathrm{CH}_{2}$, as shown in formula 2 .

$$
\frac{\mathrm{CH}_{3}}{\mathrm{CH}_{2}}=\frac{I\left(2960 \mathrm{~cm}^{-1}\right)+I\left(2870 \mathrm{~cm}^{-1}\right)}{I\left(2930 \mathrm{~cm}^{-1}\right)+I\left(2850 \mathrm{~cm}^{-1}\right)}
$$

Thus, the side chain length of liquefaction product is 0.791 .

\section{Primary analysis of Bio-liquefaction mechanism}

According to analysis above, aromatic hydrogen ratio of liquefaction product of Fushun long flame coal is 0.686 , while before liquefaction, that of Fushun long flame coal is only $0.086^{[7]}$. It is obvious that hydrogen in aromatic compounds is almost 8 times compared with before and after liquefaction, which may attribute that coal macromolecule is opened and hydrogen-added reaction occur when attached by microorganisms. On the other way, side chain of liquefaction product is 0.791 , while that of Fushun long flame coal is 0.567 , and it increases after bio-liquefaction, which may attribute to oxidation reaction on aromatic ring of Fushun coal by oxidation enzymes such as LiP and MnP excreted by white rot fungi. Except for $\mathrm{CH}_{3}$ and $\mathrm{CH}_{2}$, side chain contains other functional groups such as $\mathrm{C}=\mathrm{O}$ in ketone and ether, and $\mathrm{N}-\mathrm{H}$ in amides, as shown in FTIR analysis. 


\section{Acknowledgement}

The authors would like to thank financial support from National Natural Science Foundation of China (No. 51504134), Guizhou "125 plan" key project of science and technology project (No.Qian jiao he zhong da zhuang xiang zi [2013] 026), Guizhou province science and technology fund project(No. Qianke he J zi [2012]2306), Key Laboratory of Coal Processing and Efficient Utilization of Ministry of Education (No. CPEUKF1405), Liupanshui normal university creative team (LPSSYKJTD201401), Liupanshui normal university high level talent opening foundation(LPSSYKYJJ201402).

\section{References}

[1] WONG D. Structure and Action Mechanism of Ligninolytic Enzymes [J]. Applied Biochemistry and Biotechnology, 2009, 157(2): 174-209.

[2] FAKOUSSA R M. Coal as a substrate for microorganism: Investigation with mcrobial conversion of National Coal [D]. Bonn; Friedrich Wilhelms university, 1981.

[3] COHEN M S, GABRIELE P D. Degradation of Coal by the Fungi Polyporus versicolor and Poria monticola [J]. Applied and Environmental Microbiology, 1982, 44(1): 23-27.

[4] YAO S. P., ZHANG K., JIAO K., et al. Evolution of coal structures: FTIR analyses of experimental simulations and naturally matured coals in the Ordos Basin, China, Energy, Exploration \& Exploitation, 2011, 29: 1-20.

[5] BASARAN Y, DENIZLI A, SAKINTUNA B, et al. Bio-liquefaction/ solubilization of low-rank Turkish lignites and characterization of the products [J]. Energy Fuels, 2003, 17(4): 1068-1074.

[6] Wang ying. Bio-solution of coal and its solution mechanism[D]. Qingdao;Shandong scientific university, 2006.

[7] SHI K Y, TAO X X, LI Z, et al. Study of Construction of Fushun Coal Macromolecule Structural Model by Infrared Spectroscopy [J]. Polymer Bulletin, 2013, (3): 61-66. 